\title{
The Determinant of Islamic Bank Profitability and Stability in Indonesia Periods 2010-2017
}

\begin{abstract}
Dedi Supiyadi ${ }^{1, *}$
${ }^{l}$ STIE Indonesia Membangun

*Corresponding author. rizal.mawardi@perbanas.id

ABSTRACT

Indonesia is the largest Muslim population globally, but literacy of Islamic finance and banking is still limited, which impacts the development of sharia banking in Indonesia, including literature on Profitability and Stabil-ity in Islamic Banking. The aim of this study was to determine the profitability and stability of 34 Islamic banks in Indonesia for the period 2010-2017. This study analyzes the factors that affect Islamic banking's profitability and stability using panel data regression with fixed effect techniques. The results showed that Is-lamic banks' profitability is determined by capital, credit risk, operational efficiency, liquidity risk, asset size, stability, GDP, and inflation. The results showed that Islamic banks' profitability is determined by capital, credit risk, operational efficiency, liquidity risk, asset size, stability, GDP, and inflation. The results of Islamic banking stability found that profitability and credit risk impact bank stability, while the Asset Size, liquidity, Operating Effectiveness, inflation, and GDP do not affect the Islamic banks' stability. These findings are sig-nificant for the growth and development of Islamic banks in Indonesia
\end{abstract}

Keywords: Capital, Credit Risk, Islamic Banking, Inflation, Liquidity, Profitability, GDP, Stability.

\section{INTRODUCTION}

Islamic banking is the largest sector in the Islamic financial industry, contributing $71 \%$, or USD 1.72 trillion, of industrial assets. This sector is supported by various types of commercial banks, wholesale, and others. However, commercial banking remains a significant contributor to its growth. In a global context, Islamic banking's total assets reached US \$ 2,293 trillion, consisting of $78.9 \%$ of Islamic Bank assets, 16.8\% Sukuk, 3\% Islamic Fund, and 1.3\% Tafakul. In Indonesia, according to Islamic Financial Services Industry Stability Report 2017, the growth of Islamic banking financing and deposits have not been maximized if compared to other Muslim countries such as Bangladesh, Iran, Nigeria, Pakistan, and Oman.

This phenomenon shows that the literacy regarding Islamic finance and banking in Indonesian is still minimal. According to Bank Indonesia (BI), the Indonesian people's Islamic finance and economic literacy index have only reached $16.3 \%$ [1]. This means the level of inclusion towards Islamic financial ser-vices has not been maximized, and Islamic bank market share is still far behind ASEAN regions such as Brunei and
Malaysia and middle east countries such as Saudi Arabia, UAE, Qatar, Sudan, and Yemen. Therefore, Indonesia, as the largest Muslim country in the world, has enormous potential to pro-vide financial transaction services and provide halal products to support developing Islamic banks both regionally and globally.

The banking system in Indonesia adheres to a du-al banking system consisting of conventional and sharia banking systems. Unlike conventional banks, where the money is a commodity traded, Islamic banks treat money as a buying and selling transaction facility. Islamic banks operate based on Islamic principles and laws, that is, profit-loss sharing between banks and creditors. In general, Islamic banks' operations are a combination of commercial and investment activities that generate profits based on Islamic principles and law [2]. Based on Islamic Finance Country Index data 2017, The financial and banking industry in Indonesia ranks seventh worldwide [3].

The banking industry has an essential role in economic growth [4]. Both conventional and Islamic banks have the same goal to increase bank profitability. It has essential information for both investors and managers 
because it reflects the stability and banks' performance [5]. While the competition in the financial and banking industry in Indonesia is very tight with a high level of complexity, resulting in un-certainty in achieving bank profitability. Today Islamic banking has a vital role in the banking and fi-nancial industry. Both financial analysts and investors have begun to realize that Islamic banking is safer than conventional ones and generates higher profits. Therefore, the factors that influence Islamic banking profitability become a special issue of re-searchers.

Research on the conventional banks' profitability has been widely conducted by researchers around the word as in [6], [7]. [8], [9], [10], but studies on the Islamic banks' profitability are still very limited, including in Indonesia. The Islamic banks' profitability was first examined by [11], including research in Indonesia and research at the world level [12],[ 13], [14], with the results of studies varying from one another. Recent study conducted by [15]; [16]; [17]; [18]; [5]. find that Islamic banks' profitability is influenced by Capital, Asset Size, Credit Risk, Liquidity, Operating Efficiency, Z-Score, as well as GDP and Inflation.

Profitability is one indicator of bank performance, but bank performance will not always grow positively. Therefore, it is necessary to make an accurate prediction to see the potential for instability. Bank stability can be measured using the z-score developed by Altman in 1968 with some modifications. A healthy company tends to have a high z-score. A high z-score has a bright prospect and tends to be more stable. The higher z-score indicates more stable and directly proportional to bank profitability. According to research conducted by [19],[20], using the z-score to measure Islamic Bank Financial Stability, found that smaller Islamic Banks have a more stable than large Sharia banks, a high ZScore indicates banks have better stability since it has a smaller bankruptcy risk. Other studies found that banking profitability was influenced by Credit Risk [18, [21], [22] credit risk requires special attention of all financial institutions [23].

According to the background above, this study aims to determine the determinant of Islamic Bank Profitability and Stability in Indonesia. The study is expected to contribute, enrich previous studies' results, fill research gaps, especially on Islamic finance \& banking studies, and as empirical evidence and reference for further research.

\section{METHODS}

This research uses the explanatory research method. Explanatory research is used to determine the causal relationship between several social phenomena. The sampling technique used was purposive sampling with criteria as follows: (a) Sharia Commercial Banks \&
Sharia Business Units (b) Banks Registered at OJK (c) Published financial statements from 2010 - 2017, (d) Published financial statements in rupiah, (e) The bank presents a complete financial ratio. Based on the criteria, the research sample of 34 banks consisted of 13 Sharia Commercial Banks and 21 Sharia Business Units. The data used in this study are the annual financial statements of Islamic Banks from 2010 - 2017 with 272 observations which were obtained and collected from OJK, Bank Indonesia, the World Bank, BPS, IMF, and financial reports from each Islamic bank.

The data analysis technique used in this research is Panel Data Analysis with a fixed-effect model approach, which analyzes both the determinant of Islamic banks' profitability and Islamic bank stability profitability. Panel data is a combination of time series and crosssection data. It can provide more informative data and better detect and measure effects that cannot be observed in cross-section and time-series data.

Table 1. Definition of Variable Operations

\begin{tabular}{|c|c|c|c|}
\hline Category & Variable & Notation & Result \\
\hline $\begin{array}{l}\text { Dependent Variable } \\
\text { Profitability Ratio }\end{array}$ & ROA & Net profit $T A$ & \\
\hline Bank Stability & Z-Score & Net profit/Equity & \\
\hline \multicolumn{4}{|l|}{ Independent Variable } \\
\hline $\begin{array}{l}\text { Capital } \\
\text { Credit Risk } \\
\text { Liquidity FDR } \\
\text { Operating Effecinecy }\end{array}$ & $\begin{array}{l}\text { CAR } \\
\text { CR } \\
\text { LR } \\
\text { OER }\end{array}$ & $\begin{array}{l}\text { Equity/Assets } \\
\text { NPF/Total Financing } \\
\text { Total Financing/Total Asset } \\
\text { Bank Operational Cost/Bank }\end{array}$ & $\begin{array}{l}+ \\
- \\
+/- \\
+/-\end{array}$ \\
\hline $\begin{array}{l}\text { Bank Stability } \\
\text { Bank Size } \\
\text { Gross Domestic Product } \\
\text { Inflasi }\end{array}$ & $\begin{array}{l}\text { Z } \\
\text { BS } \\
\text { GDP } \\
\text { INF }\end{array}$ & $\begin{array}{l}\text { ROA + Equity Capital/Std. ROA } \\
\text { Natural Log of Total Asset } \\
\text { Annual real GDP growth rate } \\
\text { Current period of annual } \\
\text { inflation rate }\end{array}$ & $\begin{array}{c}+ \\
+ \\
+/- \\
+ \\
+/- \\
\end{array}$ \\
\hline
\end{tabular}

Dependent Variable. Following the literature on profitability, this study uses Return on Assets (ROA) as a proxy for Islamic Bank Profitability. ROA is used to analyze and evaluate the Islamic banks' profitability [17]; [13]. Z-Score measures bank stability, Z-Score is used to measure the Islamic banking financial stability, this proxy is used by [19]; [20].

Independent variable. This study's independent variables were divided into two categories: the internal variable bank and the macroeconomic variable. This study's bank-specific variables consist of six variables: Capital, Credit Risk, Liquidity, Operating Effectiveness, Bank Stability, and Bank Size. Macroeconomic variables, macro-economic determinants are factors that affect the bank's profitability sourced from outside the bank. It is a policy determined by the government. Based on previous research, macro-economic variables are Gross Domestic Product (GDP) and Inflation rate.

The panel data model in this study was adopted from previous studies [13]; [12]; [22], [19]; [20], [24], the equation in this study as follows: 


$$
\begin{array}{rl}
R O A=\beta_{0}+\beta_{1} & C A R_{1}+\beta_{2} C R_{2}+\beta_{3} L R_{3}+\beta_{4} O E R_{4} \\
& +\beta_{5} Z_{5}+\beta_{6} B S_{6}+\beta_{7} G D P_{7}+\beta_{8} I N F_{8} \\
& +\varepsilon \\
\text { Stability }=\beta_{0} & +\beta_{1} R O A_{1}+\beta_{2} C R_{2}+\beta_{3} L R_{3} \\
& +\beta_{4} O E R_{4}+\beta_{5} B S_{5}+\beta_{6} G D P_{6} \\
& +\beta_{7} I N F_{7}+\varepsilon
\end{array}
$$

With the above equation, the analysis has two stages, the first stage analyzing Islamic bank profitability through a fixed effects regression analysis, the second stage is analyzing bank stability with the same approach.

\section{RESULTS AND DISCUSSION}

\subsection{The determinant of Islamic Bank Profitability}

This study has two models. The first model is used to analyze bank profitability, while the second model analyzes bank financial stability. Based on the panel data regression analysis results with the fixed-effect model approach, the results of the study for the first model found that Capital, Asset Size, Credit Risk, Liquidity, Operating Efficiency, Z-Score, GDP, and Inflation greatly influence the Islamic bank profitability in Indonesia. In this study it was found that Capital Adequacy, Asset Size, Credit Risk, Operating Efficiency, and GDP had a negative effect, while liquidity, $\mathrm{z}$-score, and inflation had a significant positive effect on the Islamic bank profit-ability in Indonesia.

The results of the study found that the Islamic bank profitability has an inverse relationship with CAR. The statistical analysis results show that the CAR has a significant negative effect on Indonesia's Islamic bank profitability. This study, in line with [17], [18], stated that the highest CAR, then the capital used to handle credit risk, is more remarkable, resulting in lower profitability, higher CAR tends to reduce the level of banks profitability and increase bank costs of capital. This finding indicates that Islamic banks have not maximized capital use because Islamic banks prioritize maintaining minimum capital determined by regulations.

Table 2. Descriptive analysis

\begin{tabular}{ccccccc}
\hline Variabel & Mean & Median & Maximum & Minimum & Std. Dev. & Observations \\
\hline ROA & 2.17 & 2.04 & 11.19 & -20.13 & 2.53 & 272 \\
Z_SCORE & 7.02 & 5.16 & 81.18 & 0.84 & 8.36 & 272 \\
CAR & 17.85 & 15.85 & 76.39 & 1.98 & 11.24 & 272 \\
CREDIT_RISK & 3.30 & 2.52 & 43.99 & 0.01 & 4.29 & 272 \\
SIZE & 14.68 & 14.51 & 18.29 & 11.68 & 1.52 & 272 \\
LIUIDITY & 97.57 & 92.13 & 289.20 & 16.93 & 31.95 & 272 \\
OER & 74.33 & 79.02 & 192.60 & 9.28 & 25.75 & 272 \\
GDP & 4.64 & 4.51 & 7.48 & 2.45 & 1.68 & 272 \\
INF & 5.11 & 4.05 & 8.39 & 2.66 & 2.25 & 272 \\
\hline
\end{tabular}

Credit risk is the most common source of risk for Islamic and conventional banks, the primary source of bank failures. In line with the previous study conducted by [21]; [22]; [12], The results of the study found that credit risk had a significant and negative effect on the Islamic banks' profitability, this finding showed that the credit risk of Islamic banks in Indonesia was still very good or controlled, this was seen from the mean of 3.30. However, Islamic banks need to continue to improve the handling of failure productive assets, especially on the

\begin{tabular}{|c|c|c|c|c|c|c|}
\hline \multirow{2}{*}{$\begin{array}{l}\text { Independent } \\
\text { Variabel }\end{array}$} & \multicolumn{3}{|c|}{ ROA } & \multicolumn{3}{|c|}{ Z-Score } \\
\hline & Coefficient & t-Statistic & Prob. & Coefficient & t-Statistic & Prob. \\
\hline $\begin{array}{l}\mathrm{C} \\
\text { ROA }\end{array}$ & 5.864911 & 4.474390 & 0.0000 & $\begin{array}{l}7.950189 \\
1.308069\end{array}$ & $\begin{array}{l}3.064370 \\
12.25605\end{array}$ & $\begin{array}{l}0.0024 \\
0.0000\end{array}$ \\
\hline & -0.015849 & $\begin{array}{l}-3.456500 \\
-37255\end{array}$ & 0.0007 & & & \\
\hline $\begin{array}{l}\text { CREDIT_RISK } \\
\text { SIZE }\end{array}$ & $\begin{array}{l}-0.290418 \\
-0.183958\end{array}$ & $\begin{array}{l}-9.713255 \\
-2.494952\end{array}$ & $\begin{array}{l}0.0000 \\
0.0133\end{array}$ & $\begin{array}{r}0.202516 \\
-0.257600\end{array}$ & $\begin{array}{l}4.174567 \\
-1.746443\end{array}$ & $\begin{array}{l}0.0001 \\
0.0821\end{array}$ \\
\hline $\begin{array}{l}\text { LIOUIDITY } \\
\text { OER }\end{array}$ & $\begin{array}{r}0.002940 \\
-0.010652\end{array}$ & $\begin{array}{r}2.734479 \\
-2.691059\end{array}$ & $\begin{array}{l}0.0067 \\
0.0076\end{array}$ & $\begin{array}{l}-0.000103 \\
-0.008408\end{array}$ & $\begin{array}{l}-0.020850 \\
-1.738536\end{array}$ & $\begin{array}{l}0.9834 \\
0.0834\end{array}$ \\
\hline Z_SCORE & 0.109460 & 20.07961 & 0.0000 & & & \\
\hline $\begin{array}{l}\text { GDP } \\
\text { INF }\end{array}$ & $\begin{array}{l}-0.044602 \\
0.037726\end{array}$ & $\begin{array}{r}-2.355870 \\
2.096200\end{array}$ & 0.0193 & $\begin{array}{l}-0.007829 \\
-002898\end{array}$ & & 0.9010 \\
\hline R-squared & 0.849842 & 2.090200 & & $\begin{array}{l}0.002898 \\
0.746852\end{array}$ & 0.086973 & 0.9308 \\
\hline Adjusted R. & 0.823074 & & & 0.703017 & | & \\
\hline S.E. of $\mathrm{re}$ & 1.241388 & & & 5.103704 & & \\
\hline Durbin-Watsc & 1.807096 & & & 1.698250 & & \\
\hline F-statistic & 31.74916 & & & 17.03777 & & \\
\hline Prob(F-statistic) & 0.000000 & & & 0.000000 & & \\
\hline
\end{tabular}
productive assets of large customers, which significantly affect the soundness of banking. The level of the soundness of financing also affects the achievement of bank profits.

Table 3. Estimation Results

According to [25], enlarging the asset's size can increase bank profitability, nurture bank growth and health [26] argue that the greater the bank's size, the higher the profitability, which emphasizes economies of scale. The study results found that asset size has a negative effect on Islamic banks' profitability. This finding shows that any increase in assets can reduce the profitability of Islamic banks. This study's results are in line with the results of previous studies by [27] [28]. Increasing the bank size is considered to provide benefits that can increase profitability, including greater market power, increased technological efficiency, and secure funding at lower costs. However, an increase in size beyond a certain point can cause inefficiencies caused by an organizational bureaucracy that hinders communication.

The factor that causes banks to experience liquidity is banks' inability to maximize revenue due to the insistence on liquidity needs. The study results found that liquidity risk had a significant positive effect on bank profitability, which indicates that Islamic banking in Indonesia has adequate liquidity. This finding shows that Islamic banks' financing in the real sector has a positive impact on bank profitability. The Islamic bank can distribute loans effectively so that the number of bad loans will be small), but on the other hand, the bank is also faced with liquidity risk, the risk that the bank will experience difficulties in fulfilling short-term obligations. These findings are in line with studies [5], [12].

The results of the study found that the z-score had a significant positive effect on the Islamic banks' profitability in Indonesia. This finding showed that the benefits of funding activities increased stability and reduced the risk of bankruptcy. Companies with high z- 
scores have bright prospects and tend to be more stable, and this stability impacts bank profitability. The ZScore calculation shows the proportion of funds used for business development of assets so that the more significant the proportion of funds, the higher the ZScore, which will subsequently impact Islamic Bank profitability. This study is in line with the study results by [19]; [20].

In general, sharia banking in Indonesia has a very low probability of bankruptcy or no potential for bankruptcy, the average z-score of sharia banking is 7.02, based on Altman's z-score matrix, z-core values greater than 2.99 categorized no-bankrupt or the company is healthy. Companies that have good z-scores have bright prospects and tend to be more stable. The $\mathrm{z}$ score value is significant for policymakers to anticipate the potential for bankruptcy through anticipation steps through beneficial aspects of the company's financial and non-financial aspects.

The Islamic banking industry shows signals in an increasingly efficient direction, reflected in the declining trend in the ratio of operating costs to operating income. In line with the research results on Islamic banks in the research period for the past eight years, 2010-2017, it was found that Operating Efficiency had a significant negative effect on the profitability of Islamic banks in Indonesia. The high operating efficiency of Islamic banking, when compared to conventional banks, is caused by the economics of scale, and Islamic banking is still in the development stage. This study's results are in line with the results of the study by [16] [17].

Profitability is very sensitive to macroeconomics; high inflation reduces purchasing power due to rising product prices in the market. This research proves that for the case in Indonesia, economic growth has an impact on reducing the level of profitability of Islamic banks, given that the Islamic banking investment sector is more in the real sector, where the real sector is susceptible to GDP growth. This study's results are in line with the study results of [29, [30]

Empirical evidence in this study shows that Islamic banking's profitability in Indonesia is mostly determined by internal and external factors where CAR, Credit Risk, Asset Size, Operating efficiency, Liquidity, ZScore, economic growth (GDP), and inflation are significant, influential factors impact on the Islamic banks in Indonesia. This finding shows that the factors affecting the Islamic banks' profitability in Indonesia have not changed, so conclusions can be drawn. Islamic banks have not been able to maximize the above factors as the essential factor in increasing the Islamic banks' profitability in Indonesia, as evidenced by this study's results that the Islamic banks' probability has not been maximized. In this study, the $\mathrm{z}$-score variable was found as a new variable in Islamic banking in Indonesia as a determinant of Islamic banks' profitability.

\subsection{The determinant of Islamic Bank Stability}

A recent study on bank stability uses the z-score as a dependent variable to find the factors that influence bank instability (insolvency risk). The results of the second model analysis of Islamic bank stability measured using z-scores find that return on assets and credit risk very significant influence on the Islamic banks' stability, while the Asset Size, liquidity, Operating Effectiveness, inflation, and GDP do not affect the Islamic banks' stability, the results of this study support research, [19]; [20].

Research finds ROA as the main factor that most influences the Islamic bank's stability. This shows that profitability can strengthen Islamic banks' financial stability. Banks try to generate maximum profits by using the minimum amount input. In other words, a greater concentration of fixed assets to total assets causes a decrease in stability. This estimation shows how important it is for banks to maximize returns to achieve financial stability and to avoid failure, this is in line with the previous study by [19]; [20], [18], [24].

Next, the determinant of Islamic bank stability is credit risk. The results of the study found that credit risk has a significant effect on bank stability. This finding indicates that Islamic banks encourage to increase financing to maintain bank stability, and more stable Islamic banks tend to have less standard risks. These results are in line with the study results [19].

In general, Islamic banking in Indonesia has a very low probability of bankruptcy or no potential to go bankrupt, with an average z-score of 7.02. The z-score value is significant for policymakers to anticipate the potential for bankruptcy through anticipation steps through beneficial aspects of the company's financial and non-financial aspects. According to the asset structure, small Islamic banks have very high z-scores, meaning small Islamic banks have a more stable tendency than large Islamic banks. Most small banks have very high $\mathrm{Z}$-scores. In contrast, banks with large assets such as Bank Mandiri Syariah, BNI Syariah, Bank Muamalat Indonesia, BRI Syariah, Bank Aceh Syariah have small or unstable z-scores compared to small banks.

\section{CONCLUSION}

This study aims to determine the determinant of Islamic Bank Profitability and Stability in Indonesia. The empirical finding on this study on the first model found that Capital, Asset Size, Credit Risk, Liquidity, Operating Efficiency, Z-Score, GDP, and Inflation greatly influence the Islamic bank profitability in 
Indonesia. In this study it was found that Capital Adequacy, Asset Size, Credit Risk, Operating Efficiency, and GDP had a negative effect, while liquidity, z-score, and inflation had a significant positive effect on the Islamic bank profitability in Indonesia. The results of the second model analysis of Islamic bank stability measured using z-scores find that return on assets and credit risk very significant influence on Islamic banks' stability. Simultaneously, the Asset Size, liquidity, Operating Effectiveness, inflation, and GDP do not affect the Islamic banks' stability. Empirical evidence in this study shows that the determinant of Islamic bank profitability in Indonesia is primarily determined by internal and external factors where CAR, Credit Risk, Asset Size, Operating efficiency, Liquidity, Z-Score, economic growth (GDP), and inflation are influential factors and significant impact on the Islamic bank profitability in Indonesia. In contrast, the most important factors that influence Indonesia's Islamic banks' stability are return on assets and credit risk.

\section{ACKNOWLEDGMENTS}

Thanks and respect to STIE Indonesia Membangun, Universitas Pendidikan Indonesia, and all parties who have supported this research.

\section{REFERENCES}

[1] BI, "IndeksLiterasi untuk Akselerasi Ekonomi Syaria," Departemen Komunikasi Bank Indonesia, 2020.

[2] H. Smaoui and I. Ben Salah, "Profitability of Islamic Banks in the GCC Region," Annu. Paris Conf. Money, Econ. Manag., vol. 5, no. 1557, pp. 85-102, 2011.

[3] GIFR, Islamic Finance: A Catalyst for Shared Prosperity? 2016.

[4] S. Imran, N. Ali, A. Quality, P. P. Employee, E. Efficiency, and N. Interest, "A Study of Ten Indian Commercial Bank's Financial Performance using CAMELS Methodology," IMS Manthan, vol. VII, no. 1, pp. 1-14, 2012.

[5] H. Zarrouk, K. Jedidia, and M. Moualhi, "Is Islamic bank profitability driven by same forces as conventional banks ?," Int. J. Islam. Middle East. Financ. Manag., vol. 9, no. 1, pp. 46-65, 2016, doi: 10.1108/IMEFM-12-2014-0120.

[6] D. D. Hester and J. F. Zoellner, "The Relation Between Bank Portfolios and Earnings: An Econometric Analysis," Rev. Econ. Stat., vol. 48, pp. 372-386, 1966.

[7] B. K. Short, "The Relation Between Commercial Bank Proft Rates and Banking Concentration in
Canada, Western Europe and Japan,” J. Bank. Financ., vol. 3, pp. 209-2019, 1979.

[8] P. Bourke, "Concentration and Other Determinants of Bank Proftability in Europe, North America and Australia," J. Bank. Financ., vol. 13, pp. 65-67, 1989.

[9] P. Molyneux and J. Thornton, "Determinants of European Bank Proftability: A Note," J. Bank. Financ., vol. 16, pp. 1173-1178, 1992.

[10]A. Steinherr and C. Huveneers, "On the Performance of Differently Regulated Financial Institutions: Some Empirical Evidence," J. Bank. Financ., vol. 18, pp. 271-306, 1994.

[11] S. Haron, "The effects of management policy on the performance of Islamic banks," Asia Pacific J. Manag., vol. 13, no. 2, pp. 63-76, 1996, doi: 10.1007/BF01733817.

[12] N. Trad, M. A. Trabelsi, and J. F. Goux, "Risk and profitability of Islamic banks: A religious deception or an alternative solution?," Eur. Res. Manag. Bus. Econ., vol. 23, no. 1, pp. 40-45, 2017, doi: 10.1016/j.iedeen.2016.09.001.

[13] M. A. F. Chowdhury, M. M. Haque, and M. Masih, "Re-Examining the Determinants of Islamic Bank Performance: New Evidence from Dynamic GMM, Quantile Regression, and Wavelet Coherence Approaches," Emerg. Mark. Financ. Trade, vol. 53, no. 7, pp. 1519-1534, 2017, doi 10.1080/1540496X.2016.1250076.

[14]H. Ramlan and M. Sharrizat, "The Profitability of Islamic and Conventional Bank: Case study in Malaysia," in 7th International Economics \& Business Management Conference, 2016, vol. 35, no. October 2015, pp. 359-367, doi: 10.1016/S2212-5671(16)00044-7.

[15]R. Idris, F. Fizari Abu Hassan Asari, N. Asilah Abdullah Taufik, N. Jana Salim, R. Mustaffa, and K. Jusoff, "Determinant of Islamic Banking Institutions' Profitability in Malaysia," World Appl. Sci. JournalSpecial Issue Bols. Econ. Sustain. Bank Negara Malaysia, vol. 12, no. 1, pp. 1-7, 2011.

[16] K. Ben Khediri, B. A. M. Sami, and B.-K. Hichem, "Bank-specific, Industry-specific and Macroeconomic Determinants of African Islamic Banks," Int. J. Bus. Manag. Sci., vol. 3, no. 1, pp. 39-56, 2010.

[17] O. Masood and M. Ashraf, "Bank-specific and macroeconomic profitability determinants of Islamic banks," Qual. Res. Financ. Mark., vol. 4, no. 2/3, pp. 255-268, 2012, doi: $10.1108 / 17554171211252565$. 
[18] M. A. Trabelsi and N. Trad, "Profitability and risk in interest-free banking industries: a dynamic panel data analysis," Int. J. Islam. Middle East. Financ. Manag., vol. 10, no. 4, pp. 454-469, 2017, doi: 10.1108/IMEFM-05-2016-0070.

[19]M. Čihák and H. Hesse, "Islamic Banks and Financial Stability: An Empirical Analysis," J. Financ. Serv. Res., vol. 38, pp. 95-113, 2010, doi: 10.1007/s10693-010-0089-0.

[20] W. Rajhi and S. A. Hassairi, "Islamic Banks and Financial Stability: A Comparative Empirical Analysis Between MENA and Southeast Asian Countries," Région et Développement, vol. 37, no. 1, pp. 1-31, 2013, doi: 10.2139/ssrn.2010126.

[21] O. F. Kayode, T. M. Obamuyi, J. Ayodeleowoputi, and F. Ademolaadeyefa, "Credit Risk and Bank Performance in Nigeria," IOSR J. Econ. Financ., vol. 6, no. 2, pp. 21-28, 2015, doi: 10.9790/593306222128 .

[22] K. Djalilov and J. Piesse, "Determinants of bank profitability in transition countries: What matters most?,” Res. Int. Bus. Financ., vol. 38, pp. 69-82, 2016, doi: 10.1016/j.ribaf.2016.03.015.

[23] D. Supiyadi, D. Dodi, and A. Machmud, "Factors that Influences Credit Risk of Financing Institutions in Indonesia," in Proceedings of the 2nd International Conference on Economic Education and Entrepreneurship, 2017, vol. 1, pp. 159-163, doi: $10.5220 / 0006882401590163$.
[24]M. K. Hassan, A. Khan, and A. Paltrinieri, "Liquidity risk, credit risk and stability in Islamic and conventional banks," Res. Int. Bus. Financ., vol. 48, pp. 17-31, 2019, doi: 10.1016/j.ribaf.2018.10.006.

[25] Y. Tan, Investigating the Performance of Chinese Banks: Efficiency and Risk Features. 2016.

[26] M. Abduh and Y. Idrees, "Determinants of Islamic Banking Profitability in Malaysia," Aust. J. Basic Appl. Sci., vol. 7, no. 2, pp. 204-210, 2013.

[27] M. K. Hassan and A.-H. M. Bashir, "Determinants of Islamic Banking Profitability," Islam. Perspect. Wealth Creat., no. May, pp. 118-140, 2005, doi: 10.3366/edinburgh/9780748621002.003.0008.

[28] M. Akhtar, K. Ali, and S. Sadaqat, "Factors Influencing the Profitability of Islamic Banks of Pakistan,” Int. Res. J. Financ. Econ., vol. 66, no. 66, pp. 1-8, 2011

[29]A. T. Alharbi, "Determinants of Islamic banks profitability: international evidence," Int. J. Islam. Middle East. Financ. Manag., vol. 1, no. 1, pp. 121, 2015, doi: https://doi.org/10.1108/IMEFM-122015-0161.

[30]M. Alharthi, "The Determinants of Efficiency, Profitability and Stability in the Banking Sector: A Comparative Study of Islamic, Conventional and Socially Responsible Banks," Plymouth University, Plymouth, 2016. 